makes it possible to test the feasibility of new ideas or techniques.

Both the charities and the Medical Research Council make considerable contributions to the training of research workers by providing personal support of limited duration to younger researchers and longer-term support for research workers in maintained institutes. Figures collected during a recent survey suggest that about 1200 science graduates receive their salaries from project and programme grants provided by the charities. ${ }^{4}$ The Medical Research Council project and programme grants were providing for 1666 scientific and medical salaries on 1 January $1981 .^{3}$

The charities and the Medical Research Council both provide a considerable amount of indirect support for research by the provision of grants for travelling. They also provide funds for the purchase of new equipment, not directly related to funded projects; the organisation of scientific meetings; subscriptions to international bodies; and, in the case of the charities, funds for some health education projects.

Much of the charitable funds is given for specific research into a single disease or group of disorders. The relative sums raised reflect (to some extent) the public perception of the relative importance of these diseases. The foundations, which exist as a result of private or corporate philanthropy, are less restricted and can make contributions to basic medical science and support those areas which do not command public interest. The rank order of subjects for the charities and the Medical Research Council show remarkable similarities: in both cases the top four are cancer, general research, locomotor disorders, and neuropsychiatric disease, while aging comes at the bottom of both lists. Such lists should be treated with some caution. The first two categories in each list account for about $80^{\circ}$ " of the funds available. Cancer research accounts for $58^{\circ}$, of all the funds contributed by the charities, while in the Medical Research Council list the category "general" accounts for $61 \%$ of funds. This substantial contribution to research in the sciences basic to medicine is consistent with the Medical Research Council's major financial commitment to long-term research. Another reason for caution in interpretation is that work in one category may be directly relevant to disorders in another. The apparent gross neglect of aging by the funding bodies takes no account of research on, for example, locomotor, neuropsychiatric, and cardiovascular disorders which is of particular relevance to the aging population; and work in cell biology and biochemistry in cancer research or basic science projects may be of fundamental importance in understanding the aging process.

This survey shows, then, that the activities of the charities and the Medical Research Council are complementary though overlapping. The Medical Research Council has a major commitment to research in the sciences basic to medicine and provides an appropriate environment for such research in its units and institutions. The charities retain the larger proportion of their funds for shorter-term projects and thus have more flexibility. Their activities are also determined to an extent by the community in general. The importance of the charities' role is underlined by the observation that Britain spends little more than half that of many other industrial nations on civil research (on a per caput basis).

Clearly more money could buy more medical research-but present levels of funding will not be increased in real terms in the foreseeable future. All those bodies engaged in supporting medical research (including the universities, who provide the other limb of the dual support system) will need to use these limited funds to best effect. The charities have already taken an important step towards achieving this end by forming an association which considers strategy and organisation and by improving personal contact has provided a basis for collaboration on major projects, and, in some instances, by avoiding unnecessary duplication of effort.

David C Evered

Director,

Ciba Foundation,

London W1N 4BN

The help and co-operation of the directors and staff of the member charities of the Association of Medical Research Charities is gratefully acknowledged. It is also a pleasure to thank the staff of the Medical Research Council for their help in the collection of these data.

The Association of Medical Research Charities is staging an exhibition "Medical research today-what the charities are doing" which will be held at Fortress House, Savile Row, London W1 on Thursday 26 November from 230 to $630 \mathrm{pm}$ and Friday 27 November from 10 am to $430 \mathrm{pm}$. Admission is free.

'Booth JDL, McQuillan J, eds. Charity statistics 1980/81. 4th Annual Edition. Tonbridge, Kent: CAF Publications Ltd, 1981.

${ }^{2}$ Medical Research Council. Annual report 1979-80. London: HMSO, 1980.

${ }^{3}$ Medical Research Council. Annual report 1980-81. London: HMSO, 1981.

${ }^{4}$ Sadler J, Porter R, Evered D. Careers of non-medical graduates in British medical research. Nature $1981 ; 293: 423-6$.

\section{Immunodiagnosis in parasitic disease}

In both tropical and temperate climates the diagnosis of parasitic disease requires careful inspection of body fluids and tissues for the organisms, and for this there is no accurate substitute. When the results of these classical methods prove negative but a clinical suspicion remains of acute infection, how far do modern immunological techniques ${ }^{1}$ help?

The high concentrations of non-specific immunoglobulin found in many parasitic infections (IgE in helminthiases; $\operatorname{Ig} M$ in African trypanosomiasis) are generally not of diagnostic value. ${ }^{2}$ Attempts to use rising antibody titres in diagnosis have bedevilled parasite laboratories for many years. The tests are slow and require two or more samples, and they cannot distinguish with certainty between current and recent but burnt-out infection. The combinatiun of poor antigen definition and shortage of material has led to lack of standardisation between laboratories and hence difficulties in comparing results. ${ }^{3}$ Antibody tests may also fail if the antibody being searched for is specific for one stage within the parasite life cycle (for example for infective larvae, or adult worms or their offspring). Conversely, cross-reactivity between antigens of different parasites may also cause false-positives. Indeed, when antigen is scarce, this phenomenon has been exploited by using animal parasite antigen to diagnose human infections (for example, the dog heartworm Dirofilaria immitis for detecting onchocerciasis). With all these drawbacks, nevertheless, antibody tests are an accepted part of routine investigation, using immunofluorescent, indirect haemagglutination, or immunodiffusion methods.

Against that background, the introduction of the enzymelinked immunosorbent assay (ELISA), ${ }^{4}$ which allows rapid, multiple-sample processing using minute quantities of antigen, has been a major advance. This elegant technique can detect either antibody or antigen, depending on which is adsorbed on to the titre plate first. For developing countries, enzyme-linked immunosorbent assay has clear advantages over radio- 
immunoassays in not requiring expensive radioactive labels or maintenance of counting apparatus. ${ }^{5}$ The small amount of serum needed can be collected on filter paper from a pinprick, ${ }^{6}$ making the method suitable for epidemiological as well as individual assays. Widespread field testing is under way, and enzyme-linked immunosorbent assay is likely to supersede other tests in African ${ }^{7}$ and South American trypanosomiases, ${ }^{8}$ visceral ${ }^{9}$ and cutaneous leishmaniasis, ${ }^{10}$ filariasis, ${ }^{11}$ and schistosomiasis. ${ }^{12}$ Purification of antigens remains an obstacle for serodiagnosis in all these conditions but is rapidly progressing; for instance, the purification of schistosoma-egg antigen should further increase the test's specificity and sensitivity in this disease. ${ }^{13}$ Enzyme-linked immunosorbent assay is not yet as specific or sensitive as immunofluorescent methods in malarial antibody tests, ${ }^{14}$ probably because the antigen preparations are still crude. Evaluation of the enzyme-linked procedure is not yet complete in some other protozoal infections, but current methods such as counterelectrophoresis in occult amoebic abscess ${ }^{15}$ or immunofluorescent methods in giardiasis $^{16}$ yield acceptable results.

All these approaches rely, however, on the detection of antibodies, with its inherent disadvantages. The routine detection of circulating or tissue antigens rather than antibody would probably be the single most important advance, allowing a direct and immediate assay of a parasite's presence. Bidwell and Voller have recently described the detection by enzymelinked immunosorbent assay of malarial parasitic antigen released from disrupted red cells. ${ }^{17}$ This test is not yet as sensitive as an experienced technician's direct inspection of blood films-but it allows up to 100 samples to be processed together and the technique can be further refined. A similar procedure in helminth infections will require detailed characterisation of parasite antigens, which are not only species-specific but also stage-specific. Some have now been described. ${ }^{18}$ Extension of this work to the early infective stages of parasites is of great importance, particularly for the diagnosis of latent, asymptomatic infection typical of many of these chronic diseases.

Monoclonal antibodies have recently been used to distinguish between two closely related species of leishmania without cross-reactivity with the trypanosomes of Chagas's disease. ${ }^{19}$ This is another major development. Production of large quantities of monoclonal antibodies to this and other specific parasite antigens ${ }^{20}$ should soon be possible on a commercial scale given adequate investment. The distribution of such standard reagents would then allow uniform standards of quality control in laboratories-a move that is urgently needed. Indeed, the linking of the enzyme-linked immunosorbent assay technique with monoclonal antibodies or the relevant purified parasite antigens might encourage the production of diagnostic kits (as are now available for hepatitis-B detection) and permit their use in the simplest laboratory. The initial expense of such kits would be offset by the potential for large-scale production and distribution and by the fact that in enzyme-linked immunosorbent assay tests most of the valuable antigen or antibody can be reclaimed.
Intensive work on these aspects and subsequent field trials in the next five years may allow the developing world the standardised laboratory support on which to mount the public health programmes required to curtail the scourges of parasitic disease. Meanwhile, however, clinicians need not despair: the older diagnostic methods may not always be specific but they are at least well tested.

J K CRUickshank

Research Fellow,

Department of Immunology,

Royal Postgraduate Medical School,

London W12 0HS

C MACKENZIE

Department of Medical Helminthology,

London School of Hygiene and Tropical Medicine,

London WC1E 7HT

${ }^{1}$ Houba $\mathrm{V}$, ed. Immunological investigation of tropical parasitic diseases. Edinburgh: Churchill Livingstone, 1980.

2 Greenwood BM, Whittle HC. Immunology of medicine in the tropics. London: Edward Arnold, 1981.

${ }^{3}$ World Health Organisation. Multicentre trial of Schistosoma mansoni antigen and its test systems. Geneva: WHO, 1981.

- Voller A, Bidwell DE, Bartlett A, Edwards R. A comparison of isotopic and enzyme-immunoassays for tropical parasitic diseases. Trans $R$ Soc Trop Med Hyg 1977;71:431-7.

Gell PGH. Historical perspectives. In: Voller A, Bartlett A, Bidwell D, eds. Immunoassays for the '80s. Lancaster: MTP Press, 1981:3.

'Bruce-Chwatt LJ, Draper CC, Konfortion P. Seroepidemiological evidence of eradication of malaria from Mauritius. Lancet 1973;ii: 547-51.

- World Health Organisation. Parallel evaluation of serological tests applied in African trypanosomiasis: a WHO collaborative study. Bull WHO $1976 ; 54: 131-7$.

* Spencer HC, Allain DS, Sulzer AJ, Collins WE. Evaluation of the microenzyme-linked immunosorbent assay for antibodies to Trypanosoma cruzi. Am 7 Trop Med Hyg 1980;29:179-82.

${ }^{9}$ Hommel M, Peters W, Ranque J, Quilici M, Lanotte G. The microELISA technique in the serodiagnosis of visceral leishmaniasis. Ann Trop Med Parasitol 1978;72:213-8.

1" Roffi J, Dedet J-P, Desjeux P, Garré M-T. Detection of circulating antibodies in cutaneous leishmaniasis by enzyme-linked immunosorbent assay (ELISA). Am f Trop Med Hyg 1980;29:183-9.

$"$ Ambroise-Thomas P. Filariasis. In: Houba V, ed. Immunological investigation of tropical parasitic disease. Edinburgh: Churchill Livingstone, 1980:94

1:2 Deelder AM, Ruittenberg EJ, Kornelis D, Steerenberg PA. Schistosoma mansoni; comparison of the immunoperoxidase techniques DASS and ELISA, for human diagnosis. Exp Parasitol 1977;41:133-40.

${ }^{13}$ McLaren ML, Lillywhite JE, Dunne DW, Doenhoff MJ. Serodiagnosis of human Schistosoma mansoni infections: enhanced sensitivity and specificity in ELISA using a fraction containing $S$ mansoni egg antigens $\omega_{1}$ and $\alpha_{1}$. Trans $R$ Soc Trop Med Hyg $1981 ; 75: 72-9$.

14 Spencer HC, Collins WE, Skinner JC. The enzyme-linked immunosorbent assay (ELISA) for malaria II : comparison with the malaria indirect fluorescent antibody test (IFA). Am F Trop Med Hyg 1979;28:933-6.

15 Tosswill JHC, Ridley DS, Warhurst DC. Counter immunoelectrophoresis as a rapid screening test for amoebic liver abscess. F Clin Pathol 1980; $33: 33-5$.

${ }^{16}$ Visvesvara GS, Smith PD, Healy GR, Brown WR. An immunofluorescence test to detect serum antibodies to Giardia lamblia. Ann Intern Med $1980 ; 93: 802-5$.

17 Bidwell DE, Voller A. Malaria diagnosis by enzyme-linked immunosorbent assays. Br Med $\mathcal{F} 1981 ; 282: 1747-8$.

18 Mackenzie CD, Preston PM, Ogilvie BM. Immunological properties of the surface of parasitic nematodes. Nature $1978 ; 276: 826-8$.

19 Pratt DM, David JR. Monoclonal antibodies that distinguish between New World species of Leishmania. Nature 1981 ;291:581-3.

${ }^{20}$ Perrin I.H, Ramirez E, Lambert PH, Miescher PA. Inhibition of $\mathrm{P}$ falciparum growth in human erythrocytes by monoclonal antibodies. Nature $1981 ; 289: 301-3$. 